Berkala Ilmu Perpustakaan dan Informasi, Vol. 16, No. 1, Juni 2020, Hal. 16-20

DOI: 10.22146/bip.v16i1.280

ISSN 1693-7740 (Print), ISSN 2477-0361 (Online)

Tersedia online di https://journal.ugm.ac.id/v3/BIP

\title{
Peran pendidikan kearsipan dalam menghidupkan arsip dan kehidupan sosial
}

\author{
Arif Rahman Bramantya \\ Program Studi Kearsipan, Sekolah Vokasi, Universitas Gadjah Mada \\ Sekip Unit I, Yogyakarta, 55281 \\ e-mail: arbramantya@ugm.ac.id
}

Naskah diterima: 1 Mei 2020, direvisi: 30 Mei 2020, disetujui: 1 Juni 2020

\begin{abstract}
ABSTRAK
Pendahuluan. Pembentukan program studi bidang kearsipan di level sarjana / sarjana terapan mengarah pada upaya pengembangan pendidikan kearsipan dan pemenuhan kebutuhan arsiparis profesional. Makalah ini menjelaskan tentang pentingnya pendidikan kearsipan secara mapan dan kuat demi pengembangan keilmuan yang disesuaikan dengan standar kompetensi secara adaptif dan implementatif.

Metode penelitian. Metode yang digunakan dalam penelitian ini yaitu studi pustaka dan kualitatif.

Data analisis. Analisis data dilakukan dengan pendekatan deskriptif analitis.

Hasil dan Pembahasan. Pembentukan program studi di level sarjana / sarjana terapan yang sesuai dengan standar kompetensi yang adaptif dan implementatif akan memberi dampak terhadap kualitas lulusan yang diciptakan. Hal ini juga berpengaruh pada pengembangan keilmuan bidang kearsipan, meskipun secara kuantitas jumlah program studi kearsipan masih kurang. Kurikulum yang disusun oleh masing-masing program studi pun memiliki karakteristik tersendiri, berada di bawah fakultas atau departemen yang berbeda..

Kesimpulan dan Saran. Standar kompetensi dalam pengembangan profesional harus memastikan tujuan secara jelas bahwa bidang-bidang kompetensi yang dikembangkan disesuaikan dengan kebutuhan ilmu pengetahuan dan pemangku kepentingan. Pendidikan sejatinya untuk membentuk pribadi manusia yang mampu menyelesaikan masalah-masalah sosial di masyarakat, khususnya pendidikan kearsipan.
\end{abstract}

Kata kunci: pendidikan kearsipan; sarjana / sarjana terapan; standar kompetensi; profesional, sosial

\section{ABSTRACT}

Introduction. The establishment of archival science study programs at the undergraduate (including archival applied) level leads to efforts to develop archival education and fulfillment of the needs of professional archivists. This paper discusses the importance of established and strong archival education by implementing more effective competency standards.

Data Collection Method. The method used in this research was literature study with qualitative approach.

Data Analysis. The data was analyzed by using a descriptive-analytic approach.

Results and Discussion. The establishment of the archiavl study programs will have great impacts on the quality of the graduates. The establishment also affected the scientific development of archival science, with the fact that the number of archival science study programs is limited. The non-standard curriculum by each study program also needs to be further professionally discussed.

Conclusion. Competency standards in professional archivist development must ensure the clear objectives and tailored competency to support the archival science. Finally, archival education is to form humans' characteristics to solve social problems in society, particularly the field of archival education.

Keywords: archival education; archivist, undergraduatelapplied science; competency standards; archvive development 


\section{A. PENDAHULUAN}

Perkembangan kearsipan di Indonesia di mulai secara akademis yang mengarah pada bagaimana arsip dianggap bernilai dalam penulisan sejarah pada saat negara kolonial menemukan fondasi politik yang kuat pada akhir abad ke-19. Secara administratif dan politik, Indonesia juga mulai memperkuat kampanye diplomatik untuk perbatasan teritorial melalui ketersediaan arsip. Hal ini berpengaruh pada publik yang mulai menyadari dan menghubungkan bagaimana arsip dapat terhubung erat dengan nasionalisme dan integritas bangsa. Dari aspek sosial dan hukum, kesadaran akan fungsi arsip dimulai dari konflik agraria dan ketegangan sosial hak milik. Penyalahgunaan kekuasaan dan pelanggaran hak asasi manusia di Indonesia setelah jatuhnya rezim Suharto pun semakin memperkuat kesadaran publik tentang keterbukaan informasi yang terdapat di dalam arsip. Dari pernyataan di atas, dapat digarisbawahi bahwa keberadaan dan ketersediaan arsip memberi dampak yang sangat signifikan dalam berbagai aspek kehidupan.

Kondisi kearsipan pada masa kemerdekaan dibandingkan dengan masa Kolonial dapat dikatakan tidak teratur sebagai akibat dari penerapan sistem kearsipan yang tidak konsisten. Gejala-gejala umum kurang dikenalnya bidang kearsipan ini dapat dilihat dari rendahnya pemahaman mengenai arsip dan kearsipan, sistem pengelolaan arsip yang baik dan benar dan rendahnya penguasaan terhadap teori serta rendahnya komitmen terhadap bidang kearsipan. Dikeluarkannya Undang-Undang No. 7 Tahun 1971 tentang Pokok-Pokok Kearsipan di Indonesia paska kemerdekaan pun belum menunjukkan sikap dan perhatian serius dari pelaku pengarsipan, baik di kalangan pemerintah daerah, pemerintah pusat dan bahkan di lingkup masyarakat dalam hal penyimpanan, pemeliharaan dan pelestarian arsip (Lohanda, 2011). Dikeluarkannya Undang-Undang No. 43 Tahun 2009 tentang Kearsipan pun masih terdapat permasalahan dalam hal kualitas peraturan perundangundangan. Permasalahan tersebut mengacu pada sulitnya pengimplementasian penyelanggaraan kearsipan terutama di sektor privat karena beberapa aturan yang masih tumpang tindih dan inkonsisten.

Anggapan bahwa kearsipan merupakan ilmu yang tidak membutuhkan keahlian pun masih hinggap di benak masyarakat. Di sisi lain, kebutuhan Sumber Daya Manusia di bidang Kearsipan di Indonesia harus dipenuhi. Undangundang Kearsipan mengamanahkan bahwa setiap lembaga negara, pemerintah daerah, perguruan tinggi negeri, badan usaha milik negara (BUMN) dan badan usaha milik daerah (BUMD) untuk membentuk unit kearsipan yang dipimpin oleh arsiparis profesional dan memiliki kompetensi yang diperoleh melalui pendidikan formal bidang kearsipan. Oleh karena itu, upaya untuk meningkatkan kualitas dan kuantitas program studi kearsipan serta memperkuat hubungan antara lembaga kearsipan dengan pendidikan tinggi harus menjadi perhatian bersama (Hasanah, 2018). Pembentukan pola pikir sistematis dalam proses pembelajaran dan sinergitas dengan pemangku kepentingan pun menjadi signifikan demi pengembangan pendidikan kearsipan yang lebih baik (Bramantya \& Prasetyo, 2019).

Peran Arsip Nasional Republik Indonesia (ANRI) dalam mengembangkan keterampilan arsiparis melalui workshop, pendidikan kilat maupun sertifikasi kompetensi patut diapresiasi. Bahkan, ANRI pun siap untuk membentuk sekolah tinggi kedinasan (Manafe, 2014). Pendidikan formal dengan pembentukan sekolah tinggi bidang kearsipan di bawah perguruan tinggi Kementerian Kementerian Lain (PTKL) atau Lembaga Pemerintah NonKementerian (LPNK) menjadi perhatian serius dan perlu kajian yang mendalam agar tidak terjadi tumpang tindih dengan Perguruan Tinggi Negeri (Hasanah, Bawono, \& Rachmaji, 2017).

Penguatan terhadap bidang kearsipan tidak hanya berdomain pada Negara tetapi harus didukung dengan peningkatan Sumber Daya Manusia melalui pendidikan dan pelatihan secara komprehensif. Pendidikan berdasar pada prinsip-prinsip pedagogis yang kuat untuk menganalisis dan mensintesis informasi serta merangsang pemikiran secara kritis. Kesesuaian 
antara keluaran pendidikan dan kebutuhan dunia kerja dalam menciptakan link and match harus menjadi perhatian bersama antara dunia pendidikan dan dunia usaha. Melihat hal tersebut, kerjasama kedua sektor ini seharusnya dapat dijalin lebih erat dan berkesinambungan. Selain itu, asosiasi profesi juga dapat menjalankan perannya sebagai jembatan antara dunia pendidikan dan dunia industri dalam memberikan rekomendasi keahlian dan sekaligus sebagai pengawas kualitas lulusan. Bidang kearsipan membutuhkan profesional yang tidak hanya berkutat pada masalah teknis untuk dapat mengelola arsip, tetapi harus dapat mengikuti perkembangan jaman. Namun kesemuanya akan tidak tampak nyata jika pengakuan masyarakat terhadap bidang kearsipan masih rendah. Saat ini, penyediaan pendidikan formal bidang kearsipan masih kurang dan perkembangannya terkesan lambat (Bramantya \& Prasetyo, 2019; Hasanah, 2018; Sudiyanto, 2014). Bidang kajian kearsipan dalam Program Studi Perpustakaan dan Informasi pun memiliki kelemahan yaitu kajian ini bukan sebagai inti utama pembelajaran, sehingga kurang komprehensif dan mendalam (Hasanah, 2018).

Pembahasan tentang kearsipan (archival science) sebagai ilmu sebenarnya telah dikaji oleh banyak orang. Namun jika menilik ke belakang, rangkaian proses terkait bidang kearsipan menjadi sebuah ilmu telah mengalami fase-fase tersendiri. Dinamika perjalanan kearsipan menjadi sebuah ilmu pun turut dipengaruhi oleh aliran positivisme (Suprayitno, 2013). Di sisi lain, pemahaman arsip dan kearsipan di Indonesia dilihat dari berbagai macam perspektif. Masyarakat cenderung lebih mengenal Perpustakaan dan Ilmu Informasi (Library and Information Science/LIS) daripada kearsipan. Ilmu informasi juga belum berkembang dan belum dapat dipastikan kapan akan ada jurusan atau program studi Ilmu Informasi di Indonesia (Priyanto, 2013). Informasi sendiri dikaji dalam berbagai bidang atau disiplin ilmu. Sejak didirikannya program studi kearsipan pertama kali di Universitas Indonesia, bidang ilmu kearsipan pun belum begitu populer. Hal ini kemungkinan disebabkan oleh latar belakang sosial budaya yang melingkupinya. Pada awalnya, pemaknaan tentang keberadaan arsip dan dokumen tidak terlepas dari prinsip-prinsip pokok dalam administrasi. Begitu pula dengan perkembangan bidang kearsipan yang tidak terlepas dari ilmu informasi.

Berdasarkan latar belakang tersebut, permasalahan yang diajukan bagaimana pendidikan kearsipan dapat berdiri sendiri secara mapan dengan otonomi yang kuat untuk mencetak seorang profesional, mengingat bidang kearsipan berada pada posisi strategis di dalam lembaga atau organisasi. Kajian ini bertujuan untuk memberikan gambaran mengenai pendidikan kearsipan yang mulai berkembang ke jenjang yang lebih tinggi di level sarjana/sarjana terapan, sehingga mampu menambah Sumber Daya Manusia bidang kearsipan yang saat ini dapat dikatakan masih minim. Tidak menutup kemungkinan bahwa bertambahnya program studi bidang kearsipan di jenjang sarjana/sarjana terapan, dapat memberi peluang kepada lulusan untuk melanjutkan studi ke jenjang yang lebih tinggi di program paskasarjana. Sebuah keniscayaan bahwa lulusan bidang kearsipan juga dapat menambah jumlah pengajar di perguruan tinggi untuk membuat bidang kearsipan kuat dan mapan secara teknis dan keilmuan.

Dalam kajian ini, isu yang belum dibahas adalah pendidikan kearsipan di Indonesia kaitannya dengan pembentukan program studi baru di level D4/Sarjana Terapan yang saat ini mulai bertambah serta standar kompetensi bidang kearsipan yang dibentuk. Pembahasan dalam isu ini pun bersifat menyempurnakan atau mengembangkan penelitian-penelitan terdahulu, khususnya kajian yang dilakukan oleh peneliti Indonesia.

\section{B. TINJAUAN PUSTAKA}

Kajian tentang kecenderungan pendidikan dan penelitian bidang kearsipan yang dilakukan oleh Couture (2001) mencermati perkembangan dan penyelenggaraan pendidikan kearsipan di berbagai negara. Kajian ini sudah cukup lama, namun dapat memberi gambaran dunia pendidikan kearsipan yang mengarah pada 
integrasi ke dalam ilmu informasi, mengacu pada studi pustaka tentang pendidikan kearsipan yang diterbitkan tahun 1985-1998 serta survei terhadap institusi pendidikan bidang kearsipan, lembaga kearsipan dan peneliti bidang kearsipan di berbagai negara. Terdapat beberapa aspek penting yang dikaji, di antaranya pembentukan departemen yang berkaitan dengan kearsipan, orientasi umum dan struktur program pendidikan kearsipan, serta mata pelajaran yang diajarkan dalam program.

Kajian lain yang berkaitan dengan pembentukan pendidikan kearsipan di level pascasarjana melalui program spesialisasi dilakukan oleh Naveh (2018), menitikberatkan pada spesialisasi pendidikan kearsipan di tingkat master yang berkembang pesat di negara maju khususnya di University of California, Los Angeles (UCLA) dengan fokus utamanya pada Moving Image Archive Studies (MIAS).

Kajian dari anggota yang tergabung dalam International Council on Archives, Archival Education and Training (ICA/SAE), Hoy (2011) menjelaskan bahwa implementasi program magang dapat membangun jembatan yang efektif antara teori dan praktik, serta sebagai proses pembelajaran di tempat kerja. Program magang dapat memberikan harapan yang realistis akan peluang kerja dan karier lulusan. Oleh karena itu, program pendidikan perlu bekerja keras untuk membangun dan mengembangkan kolaborasi dengan mitra industri terkait dengan magang atau peluang karier yang disediakan. Hoy (2010) juga menjelaskan pentingnya hubungan mentoring di sektor informasi yang akan berpengaruh pada profesional dalam organisasi baru untuk dapat beradaptasi dalam membangun pengetahuan. Hubungan mentoring sebenarnya tidak terikat oleh dimensi fisik, tetapi dapat dibangun dengan komunikasi online melalui berbagai media platform untuk menambah pengetahuan, keterampilan dan karier yang akan di kembangkan.

Hasanah (2019) menitikberatkan pada belum terpenuhinya kebutuhan arsiparis profesional secara kualitas maupun kuantitas. Pendidikan kearsipan di perguruan tinggi sangat dibutuhkan, maka perlu dilakukan upaya untuk meningkatkan kualitas dan kuantitas program studi kearsipan yang ada serta menjalin hubungan antara lembaga kearsipan dan pendidikan tinggi. Bramantya dan Prasetyo (2019) juga mengutarakan pentingnya membentuk kerangka konseptual kearsipan yang kuat terkait dengan terminologi kearsipan, konsep dasar dan membuat strategi pendidikan bidang kearsipan yang inovatif, mengikuti perkembangan keilmuan baik secara nasional maupun internasional. Selain itu, diperlukan sinergitas, antara lembaga kearsipan, asosiasi profesi kearsipan, institusi pendidikan serumpun, maupun antar mahasiswa di institusi pendidikan.

Kajian-kajian di atas sebagian besar menitikberatkan pada upaya pengembangan pendidikan kearsipan, gambaran spesialisasi kompetensi dalam jenjang yang lebih tinggi kaitannya dengan profesi kearsipan, sistem pembelajaran, penambahan program pendidikan kearsipan, serta pembentukan karakter bagi calon arsiparis profesional, khususnya di negera Eropa.

\section{METODE PENELITIAN}

Kajian ini dilakukan dengan menggunakan metode studi pustaka dan metode kualitatif (Satori \& Komariah, 2013). Studi pustaka mengacu pada pengumpulan data dengan mencari informasi melalui sumber pustaka yang paling relevan dengan tema (Zed, 2014). Kajian ini menggunakan pendekatan deskriptif analitis dengan mengumpulkan materi dari sumbersumber informasi yang jelas untuk mendapatkan gambaran secara detail tentang tema pendidikan kearsipan di Indonesia. Pendekatan deskriptif analitis mengacu pada suatu metode untuk meneliti situasi melalui narasi deskriptif tentang representasi terstruktur yang berkaitan dengan sistem pendidikan kearsipan.

Pertama, perlu mencari data dan informasi yang terkait dengan tema penelitian, khususnya literatur yang berkaitan dengan pendidikan kearsipan. Sumber pustaka yang digunakan pada kajian ini sebagian besar terdiri dari jurnal ilmiah nasional dan internasional dengan tema utama tentang pendidikan kearsipan serta ilmu 
perpustakaan dan informasi. Salah satu sumber pustaka yang digunakan sebagai pisau analisis mengacu pada artikel ilmiah dari International Council on Archives, Archival Education and Training (ICA/SAE). Selain menjadi penunjang, sumber pustaka dapat menjadi pedoman agar tidak terjadi kesamaan topik pembahasan dengan penelitian yang pernah dilakukan sebelumnya.

Kedua, perlu penelusuran data terkait dengan jumlah program studi bidang kearsipan yang masih menyelenggarakan program pendidikan. Data ini merujuk pada Pangkalan Data Pendidikan Tinggi. Sedangkan penelusuran nama-nama mata kuliah mengacu pada kurikulum mata kuliah program sarjana terapan bidang kearsipan di Indonesia yang diperoleh dari situs resmi instansi pendidikan. Proses akademis dengan mengumpulkan, membaca, mencatat, dan merangkum data penelitian ini bertujuan untuk memperoleh penjelasan yang presisi tentang sistem pendidikan kearsipan. Data terkait dengan jumlah program studi bidang kearsipan dan nama mata kuliah akan dianalisis dan dinarasikan ke dalam penulisan yang sesuai dengan standar karya ilmiah. Analisis dan interpretasi data mengacu pada data terbuka yang berdasar pada pertanyaan umum tentang gambaran perkembangan pendidikan kearsipan di Indonesia dan analisis informasi yang diperoleh dalam pustaka, sehingga dapat ditemukan koherensi data-data penelitian yang dapat menjawab rumusan masalah pokok.

\section{HASILDAN PEMBAHASAN}

\section{Laporan Archival Training hingga Pembentukan Program Studi Baru}

Laporan Eric Katelaar di tahun 1980 dalam Archival Training, Republic of Indonesia, Establishment and Development of National and Regional Training Programmes in the Field of Information, yang dikeluarkan oleh UNESCO merupakan salah satu upaya dalam membangun dan mengembangkan bidang Kearsipan di Indonesia. Dari laporan tersebut disebutkan bahwa dari 197 orang yang bekerja di Arsip Nasional (sekarang ANRI), 26 di antaranya adalah lulusan universitas. 10 orang di antaranya telah menempuh pendidikan profesional: 6 orang menempuh studi di Rijksarchief School (State School for the Training of Archivist), 1 orang di Archivschule Marburg (FRG) Jerman, 2 orang di Amerika Serikat dan 1 orang di India (Katelaar, 1980). Per januari 2015 jumlah SDM ANRI berjumlah 528 orang dengan berbagai latar belakang pendidikan. Dua ratus lima puluh orang di antara mereka berlatar belakang sarjana dan menempati jumlah terbanyak (Hasanah, 2018). Dengan adanya lowongan penerimaan CPNS di tahun 2017, 2018, dan 2019, dapat dipastikan bahwa SDMANRI telah bertambah.

Saat pengembangan pendidikan bidang kearsipan, Katelaar merekomendasikan bidang lain yang sudah ada terlebih dahulu, kaitannya dengan program pembelajaran ilmu kearsipan di level universitas. Pada saat itu, Katelaar menganalisis Jurusan Ilmu Perpustakaan, Fakultas Sastra, Universitas Indonesia, sebagai perumus pendidikan kearsipan di bawah Jurusan Ilmu Perpustakaan, berkolaborasi dengan Arsip Nasional dan Lembaga Administrasi Negara (LAN). Gambar 1 merupakan visualisasi dari analisis Katelaar dalam laporan Archival Training.

Katelaar (1980) menjelaskan bahwa di masa yang akan datang dapat dipertimbangkan jurusan Ilmu Perpustakaan dan Jurusan Kearsipan untuk dapat menjadi satu yaitu School of Information Science, di mana arsiparis, pustakawan dan dokumentalis dididik dan dilatih untuk menjadi profesional di bidangnya masing-masing. Hal ini pun selaras dengan pemikiran Priyanto (2013) bahwa perlu dipertimbangkan adanya Jurusan Ilmu Informasi yang di dalamnya terdapat program studi atau minat Ilmu Perpustakaan, Kearsipan, dan Ilmu Informasi itu sendiri seperti halnya di berbagai jurusan atau fakultas Ilmu Informasi di negara-negara lain. Pertanyaan yang kemudian diajukan adalah berapa jumlah institusi pendidikan bidang Kearsipan yang menyelenggarakan program kearsipan (bukan peminatan) saat ini?. Sejak diterbitkannya laporan Archival Training tahun 1980, School of Information Science dalam angan-angan Katelaar masih menjadi wacana di Indonesia, 
namun hal itu bukan berarti tidak mungkin terjadi. Setelah keluarnya laporan Archival Training, hingga saat ini, jumlah program studi yang menyelenggarakan pendidikan kearsipan pun masih tergolong langka, tidak sebanding dengan jumlah penyelenggara program pendidikan di bidang perpustakaan dan informasi. Bidang kearsipan akan mapan jika jumlah penyelenggara pendidikan formal juga bertambah di semua jenjang, baik di level sarjana/sarjana terapan hingga program paskasarjana. Dengan demikian, masalahnya terdapat di mana?. Apakah memang benar bidang ini kurang menjual dan kurang diminati?

Tahun 2017, 2018, dan 2019 merupakan tahun emas bidang kearsipan di mana bidang ini sangat diperhatikan dan dilirik di semua instansi pemerintahan, dengan lonjakan jumlah kebutuhan arsiparis CPNS di berbagai lini. Data hasil rekap lowongan CPNS 2018 kementerian dan lembaga negara jurusan D3 Kearsipan menembus angka 227 lowongan, 54 lowongan di antaranya dari Kementerian Desa, Pembangunan Daerah Tertinggal, dan Transmigrasi. Hal ini dapat dimaknai bahwa bidang kearsipan, bidang yang sudah sangat tua, namun memiliki posisi strategis sebagai jantung dalam pelaksanaan proses bisnis lembaga dan organisasi. Oleh karena itu, salah satu aspek yang berkaitan dengan revolusi mental untuk merubah paradigma tentang arsip dan kearsipan serta kesadaran akan pentingnya keberadaan arsip menjadi urgensi dan tanggung jawab bersama. Meskipun bidang kearsipan sudah cukup tua, hubungan dengan relasi kekinian dan proses kerja pengarsipan yang berdasar pada ilmu pengetahuan hukumnya adalah wajib, karena bidang ilmu ini bersifat dinamis dan interdisipliner mengikuti perkembangan jaman. Integrasi ilmu informasi dalam kearsipan pun menjadi dominan untuk memaksa tren pengembangan keilmuan kearsipan (Couture, 2001). Jumlah program studi Kearsipan sejak keluarnya laporan Archival Training tahun 1980 hingga 2020 dapat dicermati pada Tabel 1.

Kajian yang dilakukan oleh Couture (2001) dalam Tabel 2 memperlihatkan bahwa kecenderungan ilmu kearsipan berada di bawah departemen Kearsipan. Istilah kearsipan pun dapat dimasukkan ke dalam nama departemen tersendiri. Departeman Kearsipan masih cukup dominan di beberapa perguruan tinggi tetapi ada kecenderungan menguatnya penempatan program studi Kearsipan di bawah departemen LIS. Fenomena ini bukan hanya dilihat dari tatanan nama, melainkan bahwa departemen Kearsipan memiliki karakteristik yang berbeda kaitannya dengan kurikulum yang ditawarkan. iSchool pun mulai dikembangkan dan dibentuk di berbagai negara.

Jika dibandingkan dengan program studi di Indonesia pada Tabel 1, posisi pendidikan bidang kearsipan paling dominan berada di bawah Vokasi dan Fakultas Ilmu Sosial dan Politik. Hal ini sama dengan argumen Couture bahwa bidang kearsipan di dalam departemen manapun akan memiliki ciri khas dan karakteristik masing-masing. Program Studi Sarjana Terapan Pengelolaan Arsip dan Rekaman Informasi Sekolah Vokasi UGM, berada di bawah Departemen Bahasa Seni dan Manajemen Budaya. Nama ini tidak terlepas dari akar filosofi UGM untuk menjunjung tinggi nilai-nilai kebudayaan. Mata kuliah yang ditawarkannya mempunyai ciri mengacu pada konsep pelestarian budaya. Tabel 3 merupakan kecenderungan bidang ilmu Kearsipan, Perpustakaan dan atau Ilmu Informasi, Sejarah, Ilmu Komputer kaitannya dengan bidang yang diajarkan dalam program pembelajaran kearsipan.

Sebagai tambahan bahwa pembelajaran bahasa, baik bahasa modern maupun bahasa kuno, pengetahuan teoritis dan teknis lapangan (contibutive fields) dan tata tulis dan redaksional (basic tools), metodologi penelitian, statistik termasuk dalam pembelajaran di luar inti kearsipan. Struktur kurikulum sarjana terapan bidang kearsipan di Indonesia memperlihatkan keragaman, meskipun Program Studi Sarjana Terapan Kearsipan Digital Universitas Padjajaran mengarah pada pembelajaran di bidang arsip digital. Kerja pengarsipan saat ini pun dipengaruhi oleh kemajuan teknologi, sehingga profesi arsiparis digital pun mulai bermunculan. Kerja pengarsipan harus memusatkan pada upaya untuk memposisikan ulang arsip, lembaga kearsipan dan praktisi 
kearsipan secara lebih strategis serta terus berinovasi (Millar, 2017).

Mata kuliah dasar-dasar Informasi sebagai bagian dari perpustakaan dan atau ilmu informasi terintegrasi dalam kurikulum Program Studi Sarjana Terapan Kearsipan Digital Universitas Padjajaran dan Program Studi Sarjana Terapan Pengelolaan Arsip dan Rekaman Informasi Universitas Terbuka. Sama halnya dengan mata kuliah Perilaku dan Literasi Informasi juga telah dimasukkan dalam kurikulum Program Studi Sarjana Terapan Pengelolaan Arsip dan Rekaman Informasi UGM. Selain itu, kurikulum Program Studi Sarjana Terapan Pengelolaan Arsip dan Rekaman Informasi Universitas Terbuka memasukkan mata kuliah Arsip Kelautan, Pengantar Statistik Sosial, dan Rekam Medis. Kurikulum Program Studi Sarjana Terapan Pengelolaan Arsip dan Rekaman Informasi UGM memasukkan mata kuliah Indigenous Study (pengantar) dan Mata Kuliah Lintas Disiplin Ilmu. Pembelajaran yang bersifat interdisipliner tentang ilmu-ilmu penunjang bidang kearsipan pun menjadi signifikan. Hal ini mengacu pada kualifikasi profesional yang telah berevolusi dalam praktik, maka diperlukan pengembangan spesialisasi dan fokus pada kemampuan peserta didik untuk berlatih, yang mengarah pada potensi untuk menambah kedalaman pengetahuan dan memperkuat profesi (Chawner \& Oliver, 2016). Perkembangan pendidikan LIS di Australia menawarkan keragaman pembelajaran melalui penekanan studi, di antaranya; Manajemen Informasi (Manajemen Perpustakaan dan Informasi); Ilmu Informasi (Perpustakaan dan Praktik Informasi); Sistem Informasi Bisnis (Perpustakaan dan Ilmu Informasi), dan Manajemen Informasi Digital dalam menghadapi respon di tempat kerja terhadap tuntutan lingkungan (Willard \& Wilson, 2016). Perlunya mengkaitkan ilmu kearsipan dengan departemen yang memiliki otonomi menjadi pertimbangan dalam pembentukan program studi. Beberapa kajian yang dilakukan oleh Couture (2001) telah menggunakan hasil analisisnya untuk pembentukan departemen yang didedikasikan semata-mata demi pendidikan kearsipan. Oleh karena itu, departemen kearsipan otonom dapat didirikan di tingkat universitas, meskipun saat ini di negaranegara maju telah terbentuk i-School. Pengembangan pendidikan kearsipan di Indonesia pun dapat mengarah pada penekanan studi, khususnya pembentukan program studi kearsipan di tingkat paskasarjana.

Dilihat dari aspek orientasi umum dan struktur program pendidikan kearsipan yang berkaitan dengan keseimbangan antara pembelajaran teoritis dan praktis, pembelajaran vokasional dituntut untuk secara langsung dapat menerapkan ilmu yang diperoleh pada dunia kerja. Oleh karena itu, presentase praktikum ditentukan sebesar $60 \%$, sedangkan teori sebesar $40 \%$. Hal ini selaras dengan hubungan antara teori dan praktik yang dikaji oleh Couture (2001) bahwa perkuliahan diselenggarakan rata-rata hanya $50 \%$ dari waktu mengajar dan setengahnya berupa kegiatan praktik (laboratorium, bengkel, dan lain sebagainya).

Terkait dengan program magang (internships), hasil survei Couture (2001) menunjukkan bahwa kehadiran magang bersifat wajib sekitar $60 \%$ dari program. Namun, proporsi ini bervariasi sesuai dengan tingkatan program. Pada siklus pertama tingkat sarjana, proporsi magang $80 \%$ dari program, sedangkan di siklus kedua tingkat master sebesar 39\%. Siklus ketiga di tingkat doktor sebesar 30\%. Durasi magang pun bervariasi, namun secara umum 2 bulan.

Terkait dengan definisi bidang studi, pertanyaan klasik yang sering muncul adalah bidang yang digeluti oleh masing-masing institusi pendidikan kearsipan. Tiga opsi ditawarkan oleh Couture, yaitu pertama berpusat pada manajemen arsip dinamis (records); kedua berpusat pada manajemen arsip statis (archives); dan ketiga mengacu pada integrasi antara arsip dinamis dan statis. Hasil survei menunjukkan bahwa $88 \%$ condong memilih pendekatan ketiga. Generasi Arsiparis Indonesia masa depan harus siap untuk memiliki kompetensi dalam manajemen arsip dinamis dan arsip statis, serta dapat bekerja secara profesional sesuai dengan kode etik. Profil lulusan masing-masing program studi sarjana 
terapan bidang kearsipan di Indonesia mengarah pada kompetensi tingkat ahli di bidang kearsipan (archives and records management). Pada level yang lebih tinggi, spesialisasi program pendidikan kearsipan juga akan sangat berpengaruh pada proses akreditasi sebagai salah satu dukungan timbal balik antara institusi pendidikan dan profesi (Turner, 2010).

Bidang pengetahuan lain seperti ilmu informasi, sejarah, ilmu komputer dan administrasi penting untuk ditempatkan pada kurikulum kearsipan. Hasil survei Couture (2001) menjelaskan bahwa 85\% ilmu Kearsipan bersifat interdisipliner, membutuhkan bidang ilmu lain. Fenomena konvergensi Perpustakaan dan Ilmu Informasi (LIS) di Eropa juga terkait dengan kurikulum interdisipliner, meliputi manajemen informasi dan teknologi informasi, kearsipan, studi media dan komunikasi, manajemen arsip, dan lain sebagainya. Apakah kearsipan dan perpustakaan harus diintegrasikan dalam departemen Perpustakaan dan Ilmu Informasi (LIS) atau masuk dalam peminatan? Perpustakaan dan Ilmu Informasi (LIS) dan Kearsipan telah berkembang pesat dan dapat terpisah sebagai bidang profesional yang kuat (Kajberg \& Lørring, 2015). Begitu pula dengan perkembangan program studi Kearsipan di Indonesia. Meskipun objek kajian yang dipelajari berbeda antara Perpustakaan dan Ilmu Informasi (LIS) dan Kearsipan, kesemuanya bermuara pada informasi. Teknologi informasi dan komunikasi (TIK) telah mengubah secara dramatis siklus hidup dokumen dan informasi. Berbeda dengan program pendidikan diploma tiga (D3), pendidikan di tingkat sarjana / sarjana terapan bertujuan untuk menghasilkan lulusan yang berkompeten dalam pekerjaan praktis di semua jenis lembaga dan organisasi, namun sejumlah persiapan tertentu untuk studi lanjut ke tingkat yang lebih tinggi sangat direkomendasikan (Kajberg \& Lørring, 2015).

Respon terhadap kebutuhan global dalam upaya pelestarian arsip sebagai warisan budaya demi generasi yang akan datang menjadi sebuah keharusan. Oleh karena itu, diskursus tentang pendidikan kearsipan dalam perkembangan teknologi informasi untuk menghasilkan lulusan yang berkompeten mengacu pada orang-orang yang setidaknya memiliki gelar universitas. Namun sebagian dari mereka belum mampu melakukan pendekatan berorientasi teknis. Sebaliknya, mereka membutuhkan gagasan baru untuk mengasah proses pemikiran secara kritis pada situasi yang mereka hadapi sebagai calon Arsiparis masa depan. Anderson dalam Hoy (2004) mengutarakan bahwa program pendidikan perlu membantu peserta didik untuk belajar bagaimana memperoleh pengetahuan, mentransfer pengetahuan, dan menghubungkan komponen pembelajaran di dalamnya. Hal ini didukung oleh pernyataan dan kajian dalam literatur pendidikan kearsipan bahwa pengembangan profesional perlu ditingkatkan di tempat kerja dan atau melalui asosiasi profesional setelah pendidikan formal diperoleh (Thomassen, 2001).

Pendidikan kearsipan menyiapkan Arsiparis pada level kognitif, afektif dan psikomotorik sehingga mereka lebih tahan dalam menghadapi berbagai persoalan dan perubahan zaman (Hasanah, 2019). Bahkan di era digital saat ini banyak praktisi kearsipan yang menginginkan kursus pendidikan profesional lanjutan. Clayton State University telah mengembangkan Program Magister Studi Kearsipan yang diselenggarakan secara daring. Kurikulumnya pun dibangun dan disusun berdasar pada praktik dan pengetahuan kearsipan tradisional dengan memasukkan konten yang menekankan pada arsip elektronik dan keterampilan teknologi. Pengembangan metode dan teknik pedagogis untuk melibatkan peserta didik dalam lingkungan daring menjadikan pembelajaran tanpa batas (PearceMoses, 2015). Pembelajaran daring dalam bidang kearsipan dengan kemajuan teknologi sekarang ini lebih mudah diakses dan lebih aktif terutama jika lembaga penyedia pendidikan dapat mempertimbangkan kebutuhan kearsipan di negara-negara berkembang (O'Flaherty, 2010). Bahkan gerakan Open Educational Resources (OER) bidang kearsipan dapat dikembangkan di Indonesia dengan melibatkan komunitas kearsipan dan atau Asosiasi Arsiparis Indonesia (AAI), seperti yang dilakukan oleh pustakawan di British Columbia, sebagai komunitas praktik yang dapat menjadi cara 
efektif untuk kepentingan advokasi (Smith \& Lee, 2017).

Tren kecenderungan pembelajaran daring dalam program LIS bertujuan untuk mengatasi hambatan peserta didik yang tidak masuk ke dalam sistem pendidikan tradisional karena beban kerja, komitmen dan lokasi geografis (Islam et al., 2011). Dalam konteks pembelajaran secara daring telah dilakukan oleh Program Studi Sarjana Terapan Pengelolaan Arsip dan Rekaman Informasi Universitas Terbuka dengan visi utamanya menjadi program studi yang berkualitas di bidang kearsipan melalui penyelenggaraan pendidikan tinggi terbuka dan jarak jauh (PTTJJ). Contoh lainnya yaitu pendidikan kearsipan di Universitas Mount St. Mary dengan program yang dirancang untuk mempersiapkan peserta didik dalam memberi peluang dan kesempatan karier di luar program LIS. Dari program ini, siswa telah memperoleh pemahaman tentang profesi kearsipan dan memperoleh pengetahuan dasar ilmu kearsipan untuk mengejar kesempatan magang di tingkat pemula. Bahkan jika peserta didik tidak melanjutkan karier sebagai Arsiparis, mereka telah memperoleh kesadaran tentang peran penting arsip di dalam masyarakat dan mendapat apresiasi publik untuk profesinya tersebut (Whitmore, 2018). Hal ini berkolerasi dengan kurikulum lintas disiplin yang dibentuk oleh Program Studi Sarjana Terapan Pengelolaan Arsip dan Rekaman Informasi UGM bahwa peserta didik di luar program studi dapat mengambil Mata Kuliah Lintas Disiplin bidang Kearsipan.

Penyusunan kurikulum pendidikan di jenjang sarjana/sarjana terapan bidang kearsipan bukan menambahkan mata kuliah yang terdapat di program D3 demi pemenuhan SKS (Satuan Kredit Semester), melainkan berdasar pada kebutuhan stakeholder dan standar kompetensi bidang kearsipan. Konsensus bersama dalam penentuan Capaian Pembelajaran Lulusan (CPL) untuk program studi sarjana terapan menjadi keniscayaan. Pertemuan APTIPI (Penyelenggara Pendidikan Tinggi Ilmu Perpustakaan dan Informasi Indonesia) telah menyepakati penentuan
Capaian Pembelajaran Lulusan untuk jenjang program D3.

\section{Standar Kompetensi: Menilik Pendekatan Pendidikan Kearsipan}

Pendekatan dalam pengembangan pendidikan bidang kearsipan dapat diketahui dari tinjauan standar kompetensi asosiasi profesional. Standar kompetensi Kanada dan ARMA (Association of Records Managers and Administrators) Internasional mencakup beberapa profesi terkait dengan pengetahuan dan konten di semua teori dan praktik kearsipan di tingkat dasar hingga lanjutan. Penjelasan yang dikembangkan oleh Committee on Automated Records and Techniques (CART), G4 Electronic Records Working Party dan DLM European Monitoring Committee untuk digital records mencoba mendefinisikan keunikan bagi profesi kearsipan serta memberikan landasan untuk dapat berkolaborasi dengan profesiprofesi lain (Hoy, 2004). Sementara itu, perspektif Australia dengan model record continum sebagai satu pijakan profesional tercermin dalam set standar kompetensi Australia, serta kolaborasi antara Australian Society of Archivists (ASA) dan Records Management Association of Australia (RMAA) (Mc Kemmish, 1997). Bagaimana dengan pendekatan pendidikan kearsipan di Indonesia?

Objek kajian ilmu kearsipan mengacu pada Arsip Dinamis (Records Management) dan Arsip Statis (Archives Management). Objek kajian Arsip Dinamis dibedakan menjadi dua yakni objek kajian material dan formal. Objek kajian material dari Arsip Dinamis (Records Management) adalah recorded information, sedangkan objek kajian formalnya adalah informasi yang terekam (recorded information). Kearsipan merupakan ilmu terapan yang berkaitan dengan informasi terekam dan penyajian informasi, yaitu bagaimana informasi diciptakan, disimpan, dilacak, dirawat, dan ditransmisikan (Walne, 1988). Adapun objek kajian Arsip Statis (Archives Management) terkait dengan apa yang harus diidentifikasi dan dilestarikan dari arsip statis. Fokus dari objek kajian arsip statis mengacu pada arsip sebagai 
hasil dari tata kelola (governance) untuk dilestarikan sebagai bukti (evidence) dari tata kelola, baik yang berasal dari negara, masyarakat, dan swasta. Konsep Archives mengacu pada arsip statis yang memiliki nilai abadi untuk tujuan riset, bangunan atau ruang dimana arsip statis itu disimpan, dan organisasi yang bertanggungjawab dalam menilai, mengakuisisi, melestarikan, dan membuat arsip statis tersedia publik (Ellis, 1993). Selain itu, pengetahuan kearsipan diperoleh melalui tiga paradigma perkembangan ilmu kearsipan yakni, model pra Life Cycle of the Records, model Life Cycle of the Records dan Records Continuum.

Terkait dengan profesi kearsipan, penyelenggara sertifikasi bidang kearsipan di Indonesia dapat diselenggarakan oleh Perguruan Tinggi, Asosiasi Profesi, atau Perusahaan. Di Amerika, asosiasi profesi seperti ARMA berhak menyelenggarakan uji sertifikasi. Kebijakan itu berbeda dengan asosiasi di Australia yang tidak menyelenggarakan uji sertifikasi, tetapi dilibatkan dalam akreditasi program studi (Effendhie, 2017). Saat ini, kompetensi bidang kearsipan terdapat dalam Keputusan Menteri Ketenagakerjaan Nomor 39 Tahun 2019 tentang Penetapan Standar Kompetensi Kerja Nasional Indonesia Kategori Administrasi Pemerintahan, Pertahanan dan Jaminan Sosial Wajib Golongan Pokok Administrasi Pemerintahan Bidang Kearsipan. Peraturan ini dapat menjadi acuan dalam penyelenggaraan pendidikan kearsipan bahwa standar kompetensi mengacu pada aspek teknis (kinerja) dan konsep-konsep teoritis. Selain mengacu pada standar kompetensi, pentingnya akses dan referensi kearsipan juga tercermin dalam komponen kurikulum yang dibangun untuk pengetahuan inti kearsipan dan interdisipliner. Pendekatan holistik untuk mempelajari kurikulum kearsipan juga mencakup praktikum dan peluang pembelajaran lainnya sebagai pengakuan atas fakta bahwa proses pembelajaran dapat dilakukan di luar ruang kelas (Trace \& Ovalle, 2012). Gambar 2 di bawah ini merupakan kerangka strategis dalam pengembangan keilmuan bidang kearsipan yang direkomendasikan oleh pengamat pendidikan kearsipan.
Competency-based learning mencakup kualifikasi vokasional dan kerangka pelatihan serta magang. Workplace learning mencakup sebagian besar strategi pembelajaran di tempat kerja sebagai seorang profesional. Reflective learning mencakup strategi pembelajaran yang berupaya untuk mengembangkan kemampuan akademis, diskursus teori dan praktik, dan menghasilkan pengetahuan-pengetahuan baru melalui penulisan, partisipasi pada konferensi, penelitian, dan lain sebagainya. Komitmen dan keterlibatan dalam ranah sosial akademis ini setidaknya akan membentuk minat dalam ranah profesional dan penelitian (Lau, Gillland, \& Anderson, 2012). Self-directed learning mencakup pendidikan yang lebih formal, bertujuan untuk memperluas dan mengkaji teori, serta praktik kearsipan. Self-directed learning adalah pembelajaran yang mengarah pada kualifikasi formal di level sarjana / sarjana terapan maupun paskasarjana. Dengan semakin pentingnya komponen manajemen di posisi entry level, pendidikan harus mengambil inisiatif untuk memaksa peserta didik belajar tentang keterampilan manajemen (Holley, 2016). Keahlian ini sangat diperlukan untuk dapat terlibat dengan komunitas-komunitas profesional dalam upaya membentuk spesialisasi bidang manajemen kearsipan.

Memperluas kurikulum ke dalam bidang ilmu informasi mengharuskan perluasan keahlian akademik, salah satu caranya adalah melalui rekrutmen SDM eksternal. Pendidik bidang ilmu informasi harus berusaha mengakomodasi tuntutan konteks profesional (Hider et al., 2011). Peran disiplin ilmu lain melalui konvergensi dalam menangani kebutuhan peserta didik saat ini mengarah pada upaya untuk melintasi batas-batas akademik tradisional dan kaku yang akan menciptakan hubungan baru, sebagai jembatan akademik, serta perbaharuan kurikulum yang didasarkan pada teknologi informasi dan komunikasi (Brooks, 2017). Selain itu, pembelajaran melalui MOOC, konten digital, diskusi, evaluasi, praktik, penilaian serta umpan balik merupakan elemen kurikulum yang dapat diatasi dengan crowdsourcing. Hal ini dapat menjadikan peserta didik lebih mandiri dan 
reflektif dalam komunitas pembelajaran daring, serta terlibat penuh dalam semua aspek proses pembelajaran (Paulin \& Haythornthwaite, 2016). Pendidikan perubahan berarti pemerataan di setiap lapisan masyarakat untuk mewujudkan integrasi nasional, tidak terkecuali pendidikan bidang kearsipan. Hal ini berarti bahwa mereka yang tidak menghendaki perubahan, disebut sebagai the exotic east (Kuntowijoyo, 1998).

Keterbatasan kajian tentang pendidikan kearsipan di Indonesia mengacu pada kurangnya kajian ilmiah yang ditulis oleh peneliti Indonesia, terkait dengan pembentukan program pendidikan kearsipan di level sarjana / sarjana terapan. Pembahasan kajian ini sedikit banyak menggunakan referensi yang sudah cukup lama, namun masih mempertimbangkan relevansi keilmuan bidang kearsipan. Keterbatasan kajian ini perlu untuk diungkapkan demi kesempurnaan penelitian selanjutnya.

\section{E. KESIMPULAN}

Struktur program pendidikan kearsipan di Indonesia mengacu pada aspek teori dan praktik dengan mengadopsi pendekatan yang mengintegrasikan antara arsip dinamis (records) dan arsip statis (archives). Program pendidikan kearsipan juga menekankan pada integrasi bidang ilmu lain sebagai pelengkap dan dianggap kontibutif bagi program-program dasar bidang kearsipan. Pengetahuan bidang kearsipan di Indonesia, khususnya di level sarjana/sarjana terapan dapat berkembang dengan sendirinya mengikuti perkembangan jaman, meskipun dengan kuantitas yang masih minim. Untuk mendukung hal tersebut, acuan standar kompetensi sangat penting dalam membangun dan membentuk program studi baru serta menciptakan profesional bidang kearsipan. Karena jika standar kompetensi dianggap tidak fleksibel, tidak responsif terhadap lingkungan kerja yang berbeda, praktik yang selalu berjalan dinamis, serta tantangantantangan baru, maka standar kompetensi tersebut tidak relevan dalam pengembangan profesional dan dapat ditolak oleh institusi pendidikan, stakeholder bahkan oleh lembaga kearsipan. Standar kompetensi harus memastikan tujuan secara jelas bahwa bidangbidang kompetensi yang dikembangkan sesuai dengan kebutuhan ilmu pengetahuan untuk pengembangan profesional. Standar kompetensi bidang kearsipan tidak dapat diukur melalui kinerja yang ditunjukkan dengan indikator kuantitatif karena di dalam prinsipprinsip kearsipan untuk mendukung pengembangan profesional dan untuk menyediakan kerangka kerja dibutuhkan perbaharuan teori dan praktik di semua level, baik level sarjana / sarjana terapan hingga paskasarjana. Pendidikan sejatinya untuk membentuk pribadi manusia yang mampu menyelesaikan masalah-masalah sosial di masyarakat. Pendirian program studi sarjana terapan bidang kearsipan di tingkat universitas pun harus mampu menyebarkan nilai-nilai Pancasila. Mengutip Goenawan Mohamad, definisi kesepian adalah hidup tanpa tanggung jawab sosial. Jika dihubungkan dengan pendidikan kearsipan, pendidik memiliki tanggung jawab sosial sebagai tulang punggung pengembangan ilmu pengetahuan, peserta didik, dan masyarakat. Pendidik harus terhindar dari kesepian tanpa tanggung jawab sosial bidang kearsipan.

\section{DAFTAR PUSTAKA}

Bramantya, A.R. \& Prasetyo, A. (2019). Between reality and the needs: Responsibilities of educational institutions in developing archival science in Indonesia. Record and Library Journal, 5(2), 136 149.

Brooks, C. F. (2017). Disciplinary convergence and interdisciplinary curricula for students in an information society. Innovations in Education and Teaching International, $54(3), \quad 206-213, \quad$ DOI: 10.1080/14703297.2016.1155470

Chawner, B \& Oliver, G. (2016). What if? Exploring alternative models for professional LIS education. The Australian Library Journal, 65(4), 304-316, DOI: $10.1080 / 00049670.2016 .1238433$ 
Couture, C. (2001). Education and research in archival science: General tendencies. Archival Science, 1, 157-182. https://doi.org/10.1007/BF02435646

Effendhie, M. (2017, Mei). Menengok pengembangan profesi kearsipan di Australia: Sebuah refleksi dan tantangan profesi kearsipan di Indonesia. Makalah disampaikan dalam Seminar Nasional Kearsipan Program Studi Kearsipan Sekolah Vokasi UGM, Indonesia. Retrieved from https://www.academia.edu/ $33104851 /$ MENENGOK PENGEM BANGAN PROFESI KEARSIPAN DI

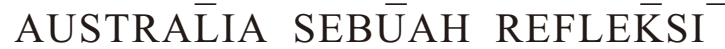
DAN_TANTANGAN_PROFESI_ KEAR $\overline{S I P A N}$ DI INDONESIA

Ellis, J. (ed). (1993). Keeping archives (2nded.). Melbourne, Australia: DW Thorpe.

Hasanah, S. (2018). Penguatan pendidikan bagi arsiparis. Jurnal Kearsipan, 13(1), 1-18. http://jurnalkearsipan.anri.go.id/index.php /ojs/article/view/44

Hasanah, S., Bawono, H., Rachmaji, A. S. (2017). Urgensi perguruan tinggi kedinasan kearsipan dan prospeknya. Yogyakarta: Diandra.

Hider, P., Kennan, M. A., Hay, L., McCausland, S., \& Qayyum, A. (2011). Moving from LIS to IS+L: curriculum renewal at Charles Sturt University. The Australian Library Journal, 60(3), 205-217, DOI: 10.1080/00049670.2011.10722617

Holley R. P. (Column Editor) (2016) Providing LIS students with management skills. Journal of Library Administration, 56(5), 638-646, DOI: $\quad 10.1080 /$ 01930826.2016 .1186984

Hoy, M. (2011). Building pathways to working with collections: Can internships and student work experience help?. Australian Academic \& Research Libraries, 42(1), 2942, DOI:10.1080/00048623.2011. 10722202

Hoy, M. (2010). Making the most out of mentoring relationships: Experiences of new professionals. Comma, 2010(1), 109121.
Hoy, M. (2004, Agustus). Professional development in archival institutions: The contribution of competency standards. Archives, Memory \& Knowledge. Proceedings of the XVth International Congress on Archives, Wien. Retrieved from http://www.ica-sae.org/ Marian $\% 20$ Hoy $\% 20 I C A \% 20$ Congress $\% 2$ 02004\%20paper.pdf.

Islam, S., Md., Kunifuji. S, Hayama, T \& Miura, M. (2011). Towards exploring a global scenario of e-learning in library and information science schools. The International Information \& Library Review, 43(1), 15-22, DOI: 10.1080/ 10572317.2011.10762876

Katelaar, E. (1980). Archival training. Paris: UNESCO.

Kajberg, L. \& Lørring, L. (2015). European curriculum reflections on library and information science education. Denmark: The Royal School of Library and Information Science

Kuntowijoyo. (1998). Pendidikan perubahan. Almanak Muhammaddiyah tahun 1419 Hijriyah (1998-1999 Miladiyah). Yogyakarta: Majelis Pustaka Pimpinan Pusat Muhammadiyah.

Lau, A. J., Gilliland, A. J., \& Anderson, K. (2012). Naturalizing community engagement in information studies. Information, Communication \& Society, 15(7), 991-1015, DOI: 10.1080/1369118X. 2011.630404

Lohanda, M. (2011). Membaca sumber membaca sejarah. Yogyakarta: Penerbit Ombak.

Manafe, D. (2014,18 Agustus). Arsip Nasional akan bangun sekolah tinggi kearsipan. Berita Satu. Retrieved from https:// www.beritasatu.com/pendidikan/203321arsip-nasional-akan-bangun-sekolahtinggi-kearsipan.html

McKemmish, S. (1997, September). Yesterday, today and tomorrow: A continuum of responsibility. Proceedings of the Records Management Association of Australia 14th National Convention. Retrieved from https://doi.org/10.4225/03/580576155de5 7. 
Millar, L. (2017). On the crest of a wave: Transforming the archival future. Archives and Manuscripts, 45(2), 59-76, DOI: 10.1080/01576895.2017.1328696

Naveh, J. (2018) Education against the grain: Examining the evolution of media archival training at UCLA. Journal of Archival Organization, 15(3-4), 121-132, DOI: 10.1080/15332748.2019.1613317

O'Flaherty, V. B. (2010) Online training programs, an opportunity to be developed Distance learning: some personal perspectives. Comma, 2010(1), 85-90.

Paulin, D. \& Haythornthwaite, C. (2016). Crowdsourcing the curriculum: Redefining e-learning practices through peer-generated approaches. The Information Society, $32(2), \quad 130-142, \quad$ DO I : 10.1080/01972243.2016.1130501

Pearce-Moses, R. (2015, October). Teaching archival technology online. Proceedings of International Council on Archives - Section for Archival Education and Training Annual Conference, Spain. Retieved from http://www.ica-sae.org/proceedings/ girona2014/Pearce-Moses\%20final.pdf

Priyanto, I. F. (2013). Apa dan mengapa ilmu informasi?. Jurnal Kajian Informasi dan Perpustakaan, 1(1), 55-59.

Satori, D., \& Komariah, A. (2013). Metodologi penelitian kualitatif. Bandung: Alfabeta.

Smith, B., \& Lee, L. (2017). Librarians and OER: Cultivating a community of practice to be more effective advocates. Journal of Library \& Information Services in Distance Learning, 11(1-2), 106-122, DOI: 10.1080/1533290X.2016.1226592

Sudiyanto. (2014). Upaya pemerintah menyiapkan SDM kearsipan melalui pendidikan formal. Buletin Khazanah, 7(1), 3-14.
Suprayitno. (2013). Positivisme dalam kearsipan. Buletin Khazanah, 6(1), 27-39.

Thomassen, T. (2001, September). Modelling and re-modelling archival education and training. European Conference for Archival Educators and Trainers International Council of Archives, Germany. Retrieved from http://www.ica-sae.org/ mrconfpaper1.html

Trace, C. B. \& Ovalle C. J. (2012). Archival reference and access: Syllabi and a snapshot of the archival canon. The Reference Librarian, 53(1), 76-94, DOI: $10.1080 / 02763877.2011 .596364$

Turner, M. (2012). The accreditation of training programmes in archive asministration and record management in The UK and Ireland, Comma, 2010(1), 39-45.

Walne, P. (1988). Dictionary of archival terminology /dictionnaire de terminologie archivistique English and French. München, Germany: K.G Saur.

Whitmore, J. J. (2018). Intro to archival science: Developing an undergraduate archival elective outside of a LIS program. Journal of Archival Organization, 15(3-4), 145158, DOI: $\quad 10.1080 / 15332748.2019$. 1613313

Willard, P., \& Wilson, C. S. (2016). Reflection on: "Australian professional library and information studies education programs: Changing structure and content". Australian Academic \& Research Libraries, 47(4), 261-269, DOI: 10.1080/00048623.2016.1250597

Zed, M. (2014). Metode penelitian kepustakaan. Jakarta: Yayasan Obor Indonesia. 


\section{DAFTAR GAMBAR}

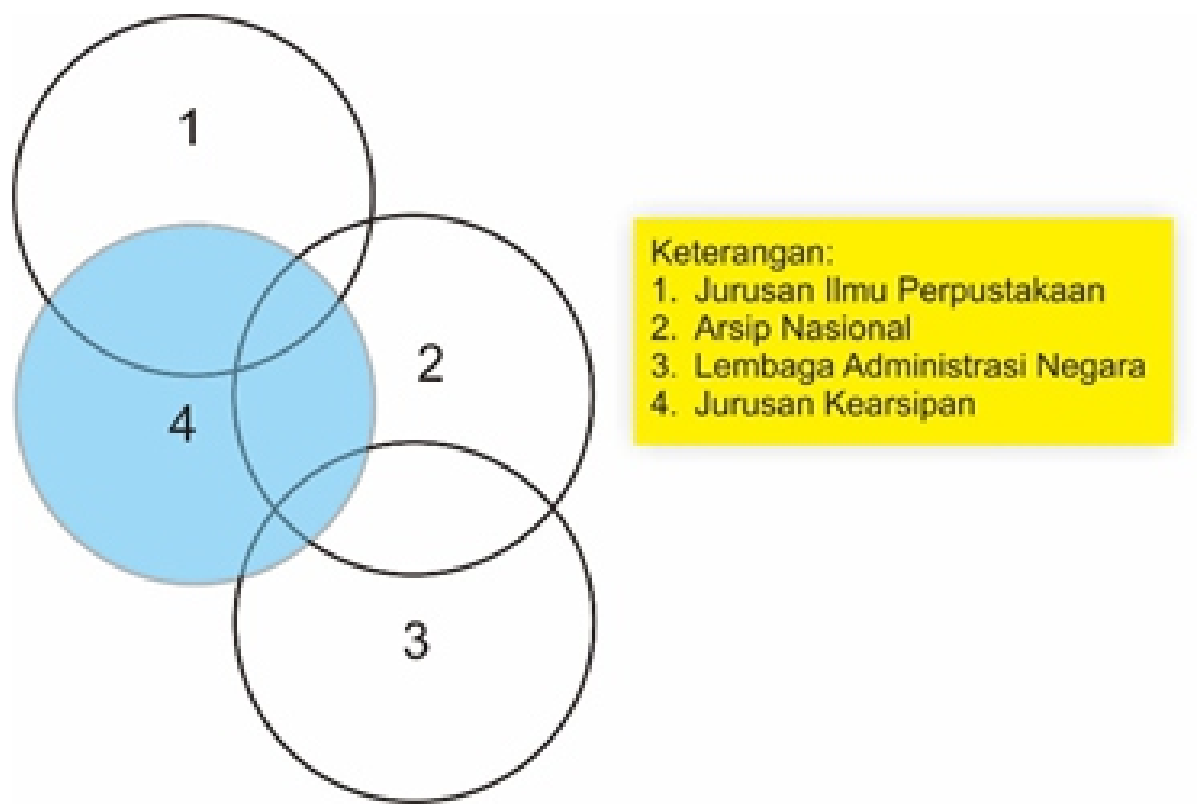

Gambar 1. Visualisasi (Katelaar, 1980)

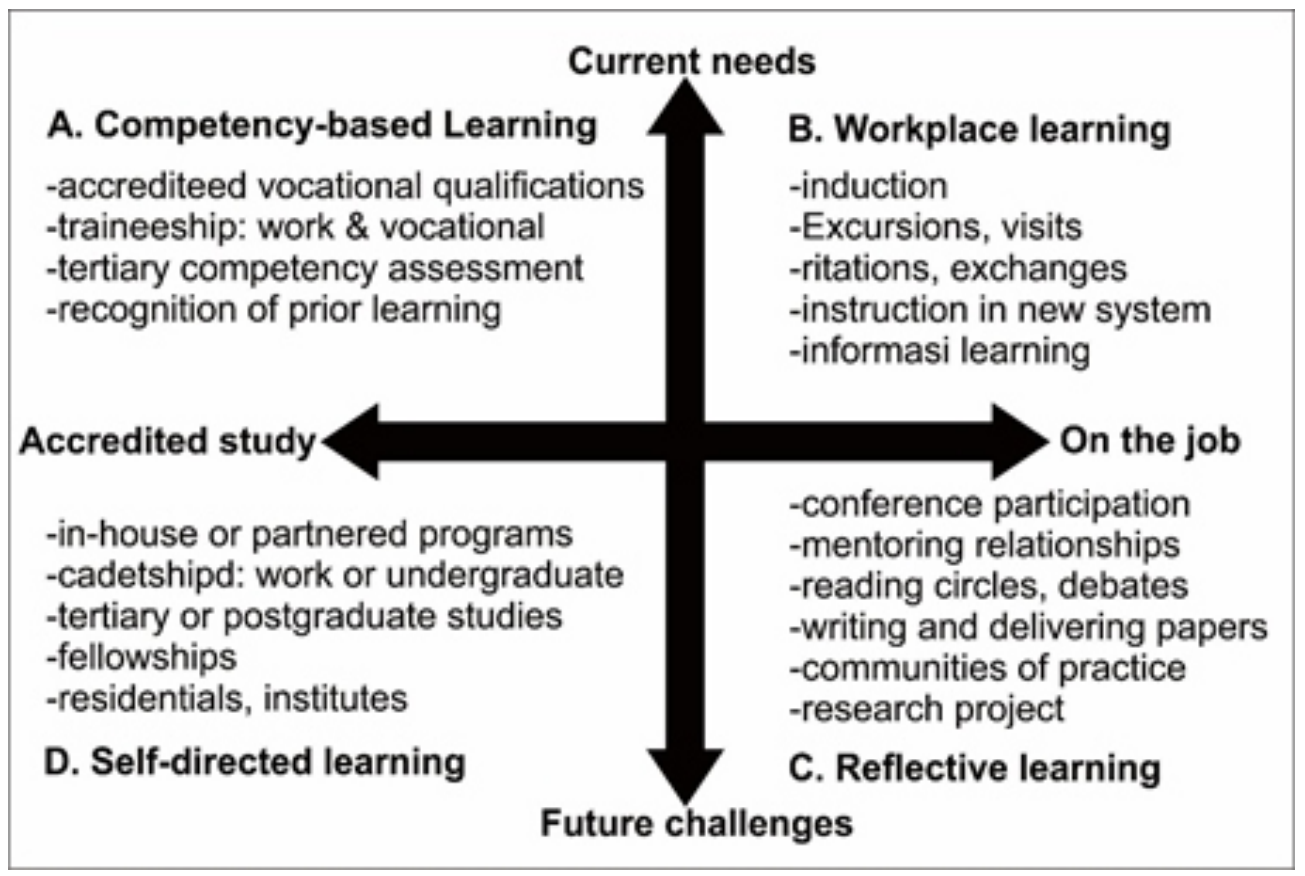

Gambar 2. Capaian pembelajaran dan kerangka strategis pengembangan keilmuan bidang kearsipan (Hoy, 2004:24) 


\section{DAFTAR TABEL}

Tabel 1. Program Studi bidang kearsipan jenjang Diploma III dan Sarjana Terapan

\begin{tabular}{|c|c|c|c|c|}
\hline No & Nama Program Studi & Universitas & $\begin{array}{l}\text { Tahun pembukaan } \\
\text { Program Studi }\end{array}$ & Jurusan/Departemen/Fakultas \\
\hline 1 & $\begin{array}{l}\text { S.Tr (D4) Pengelolaan } \\
\text { Arsip dan Rekaman } \\
\text { Informasi }\end{array}$ & Universitas Terbuka & 2007 & $\begin{array}{l}\text { Jurusan Ilmu Komunikasi, } \\
\text { Fakultas Hukum, Ilmu Sosial } \\
\text { dan Ilmu Politik }\end{array}$ \\
\hline 2 & $\begin{array}{l}\text { S.Tr (D4) Pengelolaan } \\
\text { Arsip dan Rekaman } \\
\text { Informasi }\end{array}$ & $\begin{array}{l}\text { Universitas Gadjah } \\
\text { Mada }\end{array}$ & 2019 & $\begin{array}{l}\text { Departemen Bahasa, Seni dan } \\
\text { Manajemen Budaya, Sekolah } \\
\text { Vokasi }\end{array}$ \\
\hline 3 & $\begin{array}{l}\text { S.Tr (D4) Kearsipan } \\
\text { Digital }\end{array}$ & $\begin{array}{l}\text { Universitas } \\
\text { Padjajaran }\end{array}$ & 2019 & $\begin{array}{l}\text { Fakultas Ilmu Sosial dan Ilmu } \\
\text { Politik }\end{array}$ \\
\hline 4 & $\begin{array}{l}\text { S.Tr (D4) Manajemen } \\
\text { Rekod dan Arsip }\end{array}$ & Universitas Indonesia & 2020 & Vokasi \\
\hline 5 & D3 Kearsipan & $\begin{array}{l}\text { Universitas } \\
\text { Diponegoro }\end{array}$ & 1994 & Fakultas Ilmu Budaya \\
\hline 6 & D3 Kearsipan & $\begin{array}{l}\text { Universitas Gadjah } \\
\text { Mada }\end{array}$ & 1994 & $\begin{array}{l}\text { Departemen Bahasa, Seni dan } \\
\text { Manajemen Budaya, Sekolah } \\
\text { Vokasi }\end{array}$ \\
\hline 7 & D3 Kearsipan & $\begin{array}{l}\text { Universitas } \\
\text { Tanjungpura }\end{array}$ & 2014 & $\begin{array}{l}\text { Fakultas Ilmu Sosial dan Ilmu } \\
\text { Politik }\end{array}$ \\
\hline
\end{tabular}

Sumber: data primer yang diolah, 2020

Tabel 2. Departemen yang mengusung program kearsipan di berbagai Negara

\begin{tabular}{clcc}
\hline No & \multicolumn{1}{c}{ Departemen } & Jumlah & Persentase \\
\hline 1 & Perpustakaan dan atau ilmu informasi (LIS) & 17 & 25 \\
2 & Kearsipan, Perpustakaan dan atau ilmu & 8 & 12 \\
& informasi & & 19 \\
3 & Sejarah & 13 & 31 \\
4 & Kearsipan & 21 & 6 \\
5 & Dokumentasi & 4 & 2 \\
6 & Lainnya & 1 & 5 \\
7 & Unit non departemen & 3 & \\
& Total & 67 & \\
\hline
\end{tabular}

Sumber: Couture, 2001 
Tabel 3. Kecenderungan bidang ilmu yang disusun dalam program kearsipan

\begin{tabular}{|c|c|c|c|}
\hline Kearsipan & $\begin{array}{l}\text { Perpustakaan dan } \\
\text { atau ilmu informasi }\end{array}$ & Sejarah & Ilmu komputer \\
\hline $\begin{array}{l}\text { General courses: } \\
\text { 1. Fundamental archival } \\
\text { Science } \\
\text { 2. Archives management } \\
\text { 3. Records management } \\
\text { Archival Function: } \\
\text { 1. Conservation } \\
\text { 2. Description } \\
\text { 3. Classification } \\
\text { 4. Appraisal } \\
\text { 5. Dissemination } \\
\text { 6. Acquisition } \\
\text { 7. Creation (production } \\
\text { of records) } \\
\text { Study of the document: } \\
\text { 1. Paleography } \\
\text { 2. Diplomatic } \\
\text { 3. Typology of archives } \\
\text { Other subjects: } \\
\text { 1. Legislation and legal } \\
\text { 2. Aatters } \\
\text { 3. National } \\
\text { 4. Historical sources } \\
\text { 5. Publishing } \\
\text { 6. Other subjects }\end{array}$ & $\begin{array}{l}\text { Information process: } \\
\text { 1. Classification and } \\
\text { indexation } \\
\text { 2. Information retrieval } \\
\text { 3. Information analysis } \\
\text { Fundamental theories: } \\
\text { 1. Information sciences } \\
\text { 2. Library science } \\
\text { 3. Documentation theory } \\
\text { Other subjects: } \\
\text { 1. Institutions } \\
\text { 2. Documentary products } \\
\text { 3. Information systems } \\
\text { 4. Information resources } \\
\text { 5. Information management }\end{array}$ & $\begin{array}{l}\text { 1. National history } \\
\text { 2. History of the } \\
\text { administration } \\
\text { 3. History of document } \\
\text { 4. History of institution } \\
\text { 5. Methodology and } \\
\text { sources } \\
\text { 6. General history } \\
\text { 7. Historiography }\end{array}$ & $\begin{array}{l}\text { Computer science and } \\
\text { archives } \\
\text { Management: } \\
\text { 1. Information } \\
\text { technologies } \\
\text { 2. Electronic records and } \\
\text { archives } \\
\text { 3. automation } \\
\text { General (non-archival) } \\
\text { computer applications } \\
\text { 1. Introduction to } \\
\text { computer science }\end{array}$ \\
\hline
\end{tabular}

Sumber: (Couture, 2001) 